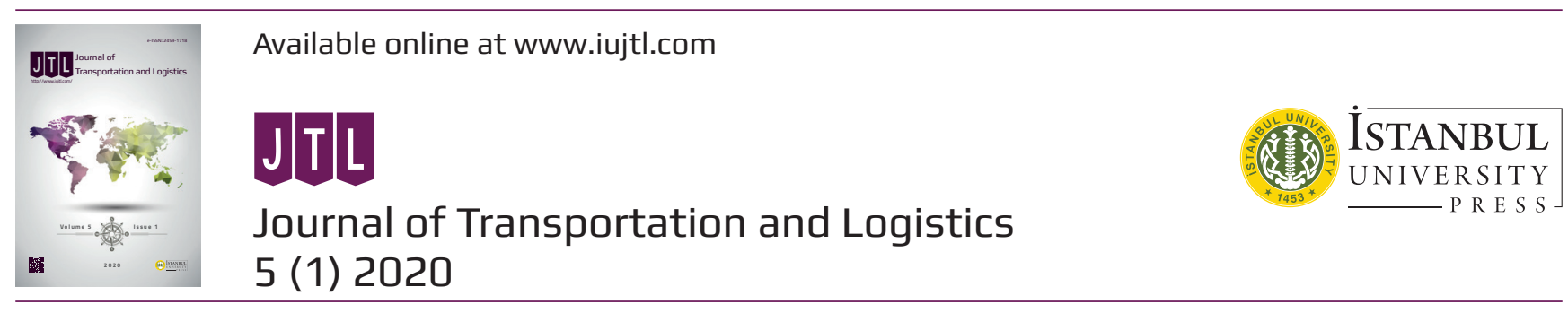

\title{
Controller Design for Roll Motion of a Planing Hull From a Safe Transportation Perspective
}

\section{Güvenli Ulașım Bakıș Açısıyla Bir Kayıcı Teknenin Yalpa Hareketi İçin Kontrolcü Dizayni}

\author{
Hakan Demirel ${ }^{1}$ (i), Fuat Alarçin ${ }^{2}$ (1)
}

\begin{abstract}
The issue of safe navigation in the maritime sector is becoming more important day by day. This situation is valid not only in terms of passenger and cargo transportation, but also in different maritime operations. Based on this point, much equipment is used in order to perform safe navigation in ships for different sea states such as wind, wave, etc. This equipment is classified as active and passive systems and can be applied to different types of ships. Active stabilizer systems are frequently used, especially for ship types where speed and maneuverability are high, as instantaneous responses are important. Although there are many active systems used, active roll stabilizer fin systems are the most common. At this point, this paper describes an application of LMI (Linear Matrix Inequality) based robust and saturated $\mathrm{H}_{2}$ state feedback control to roll motion of the planing hull via the fin stabilizer. In the mathematical model, nonlinearities are expressed through damping and restoring terms. Based on the planing hull roll motion mathematical model, we also present a state space model suitable for simulation and control applications. Nondimensional lift coefficients of the fin stabilizer for different angles of attack are calculated with Star CCM+ package software. Both controlled and uncontrolled conditions are examined for the maximum lift coefficient. As a result, the efficiency of the proposed approach for safe transportation was demonstrated with the simulation results and an effective study was carried out by reducing the amplitudes of the roll motion to reasonable levels.
\end{abstract}

Keywords: LMI (Linear Matrix Inequality), Fin Stabilizer, Safety Transportation, Controller Design, Roll Motion

\section{Öz}

Denizcilik sektöründe güvenli seyir konusu her geçen gün daha da önem kazanmaktadır. Sadece yolcu ve yük taşımacılığı açısından değil, farklı deniz operasyonlarında da bu durum geçerliliğini korumaktadır. Bu noktadan yola çıkarak gemilerde, denizlerde karşılaşılabilecek farklı şiddetteki rüzgar, dalga vb durumlarda güvenli seyir gerçekleştirilebilmesi amacıyla birçok ekipman kullanılmaktadır. Bu ekipmanlar aktif ve pasif sistemler olarak sınıflandırılmakta ve farklı gemi tiplerine uygulanabilmektedir. Özellikle hız ve manevra kabiliyetinin yüksek olduğu gemi türleri için anlık tepkilerin önemli olması nedeniyle aktif dengeleyici sistemler sıklıkla kullanılmaktadır. Kullanılan birçok aktif sistem olmakla beraber, aktif yalpa dengeleyici fin sistemleri en yaygın olanıdır. Bu bağlamda, çalışmada aktif yalpa dengeleyici fin sistemi ile kayıcı bir teknenin yalpa hareketi için, Doğrusal Matris Eşitsizlikleri tabanlı, dayanıklı ve doyumlu $\mathrm{H}_{2}$ durum geri beslemeli kontrol uygulaması tanımlanmaktadır. Matematik modelde doğrusal olmayan ifadeler, sönüm ve doğrultucu moment terimleriyle ifade edilmektedir. Kayıcı teknenin yalpa hareketinin matematik modeline dayalı olarak ayrıca durum-uzay modeli, kontrol uygulaması ve simülasyon için sunulmaktadır. Aktif fin yalpa dengeleyici sistemin farklı açılardaki boyutsuz kaldırma katsayıları Star CCM+ programıyla hesaplanmıştır. Kontrollü ve kontrolsüz durumlardaki yalpa genlikleri maksimum kaldırma katsayısı için incelenmiştir. Sonuç olarak, güvenli bir ulaşım için önerilen yaklaşımın verimliliği simülasyon sonuçlarıyla gösterilmiş ve yalpa hareketinin genlikleri makul seviyelere düşürülerek etkili bir çalışma gerçekleştirilmiştir.

Anahtar Kelimeler: Doğrusal Matris Eşitsizlikleri, Yalpa Dengeleyici Fin, Güvenli ulaşım, Kontrolcü Dizaynı, Yalpa Hareketi

Submitted: $20.02 .2020 \bullet$ Accepted: 12.03 .2020

\footnotetext{
1 Corresponding author: Hakan Demirel / Zonguldak Bülent Ecevit University, Department of Marine Engineering, Zonguldak, Turkey E-mail: hakandemirel@beun.edu.tr, ORCID: 0000-0002-7579-7064

2 Fuat Alarçin / Yıldız Technical University, Department of Marine, Istanbul, Turkey, E-mail: alarcin@yildiz.edu.tr, ORCID: 0000-0003-1073-0368

Citation: Demirel, H., Alarcin, F. (2020). Controller design for roll motion of a planing hull from a safe transportation perspective. Journal of Transportation and Logistics, 5(1), 1-11. https://doi.org/10.26650/JTL.2020.0010
} 


\section{Introduction}

Controlling roll motion of ships has a significant role in severe sea states. Large amplitude roll motion can easily cause capsizing due to the effects of wind, wave and flow. In order to reduce the roll motion, fin stabilizers, anti-rolling tanks, gyroscopic stabilizers, bilge keels and rudder roll stabilizer etc., have been used on ships (Perez, 2005; Chadwick, 1955).

In the literature, there are many roll stabilizer system applications. Saari \& Khichane (2013) applied $\mathrm{H}_{\infty}$ control on a container ship to reduce the undesirable rolling effect taking into account the real conditions using the rudder. Alarcin \& Gulez (2007) described the use of a neural network controller for roll stabilisation of a fishing boat using the rudder. Alternatively, active u-tank stabilizer can be used for roll reduction. Holden et al. (2009) used active u-tank stabilizer for roll motion reduction and suggested a nonlinear backstepping controller to stability of roll. Marzouk \& Nayfeh (2009) investigated the performance of passive and active anti-roll tank systems and compared their performance in various sea states.

Nevertheless, the fin stabilizer is the most effective device to weaken the rolling motion. Hickey et al. used PID controller for reducing roll motion with fin stabilizer (Hickey, Johnson, \& Katebi, 1999). Ghassemi et al. (2010) obtained effective results using a combined neural network and PID for roll control of ship with small draught. Bai (2014) applied the Adaptive Fuzzy Output-Feedback Method to ship roll stabilization with the fin control system and revealed the effectiveness of the proposed approach with simulations.

A number of control problems were investigated by many researchers, in these studies, different models examined and various control methods were applied (Ku et al., 2015; Qi et al., 2014; Guo et al., 2012; Xiuyan et al., 2014; Townsend et al., 2014).

In this paper, the control of nonlinear roll motion of a planning hull is examined. Section 2 deals with the mathematical model based on nonlinear restoring moment and damping impact including the fin roll stabilizer system dynamics. Section 3 expresses designing LMI - based robust and saturated $\mathrm{H}_{2}$ state feedback controller. Section 4 and 5 discuss results and conclusion.

\section{Mathematical Model of Roll Motion}

Different type equations of nonlinear roll motion are suggested by many researchers. These equations can occur from several representations of damping and restoring moments associated with the mathematical model. In the present study, B1 type damping and quantic restoring are used for the mathematical model (Taylan, 1990) and expressed as;

$$
\begin{aligned}
& \left(\mathrm{I}+\mathrm{I}_{x x}\right) \ddot{\varphi}+\mathrm{B}_{\mathrm{L}} \dot{\varphi}+\mathrm{B}_{\mathrm{N}} \dot{\varphi}|\dot{\varphi}|+\Delta\left(\mathrm{C}_{1} \varphi+\mathrm{C}_{3} \varphi^{3}+\mathrm{C}_{5} \varphi^{5}\right)=M_{W}+M_{F} \\
& M_{W}=\omega_{\mathrm{e}}^{2} \alpha_{m} I \cos \left(\omega_{e} t\right) \\
& M_{F}=-\frac{\rho V^{2} A_{f} C_{L}}{\mathrm{I}+\mathrm{I}_{x x}}\left(\alpha_{f}+\frac{\dot{\varphi} l f}{V}\right) l f
\end{aligned}
$$


If the equation is divided through $\mathrm{I}+\mathrm{I}_{x x}$, the equation is expressed as below

$$
\begin{aligned}
& \ddot{\varphi}+\delta_{1} \dot{\varphi}+\delta_{\mathrm{n}} \dot{\varphi}|\dot{\varphi}|+\Delta\left(m_{1} \varphi+m_{3} \varphi^{3}+m_{5} \varphi^{5}\right)= \\
& \lambda_{e} \omega_{\mathrm{e}}^{2} \alpha_{m} \cos \left(\omega_{e} t\right)-\delta_{2} \alpha_{f}-\delta_{3} \dot{\varphi}
\end{aligned}
$$

Where,

$$
\begin{aligned}
& \delta_{1}=\frac{\mathrm{B}_{\mathrm{L}}}{\left(I+I_{x x}\right)} \\
& \delta_{n}=\frac{\mathrm{B}_{\mathrm{N}}}{\left(I+I_{x x}\right)}
\end{aligned}
$$

Among all ship motions, roll motion is the most important response of a ship to calculate because large-amplitude roll motions may lead to capsizing, cargo shift, loss of deck cargo, and other undesirable consequences. The roll damping plays a very important role for roll motion so that it should be calculated correctly for a better estimation of roll motion. One of the most common methods to calculate the roll damping coefficient is Ikeda's estimation method. According to Ikeda (1978), see also Himeno (1981), the total equivalent linear roll damping coefficient can be divided into five components. These components are composed of skin friction damping, eddy damping, wave damping, lift damping and bilge keel damping. The method was proposed to predict the roll damping of a conventional cargo ship and furthermore it was developed for a hard-chine hull, high speed displacement type ships and planning crafts. In this paper, Ikeda's estimation method was used to calculate the roll damping coefficients of the used model (Ikeda \& Katayama, 2000).

As mentioned above, the roll damping coefficient can be divided into five components;

$\mathrm{B}_{44}=\mathrm{B}_{\mathrm{F}}+\mathrm{B}_{\mathrm{W}}+\mathrm{B}_{\mathrm{E}}+\mathrm{B}_{\mathrm{LD}}+\mathrm{B}_{\mathrm{BK}}$

where $\mathrm{B}_{\mathrm{F}}$ is the frictional damping, $\mathrm{B}_{\mathrm{W}}$ is the wave damping, $\mathrm{B}_{\mathrm{E}}$ is the eddy damping, $\mathrm{B}_{\mathrm{BK}}$ is the bilge keel damping and $\mathrm{B}_{\mathrm{LD}}$ is the lift damping. In this study, there is no bilge keel attached to the hull so that this component is zero. Eddy damping contribution decreases due to the high speed. Therefore, the lift component of the roll damping becomes dominant at high forward speed as mentioned by Katayama and Ikeda (1995) Figure 1 shows the results of the roll damping coefficients at various forward speeds.

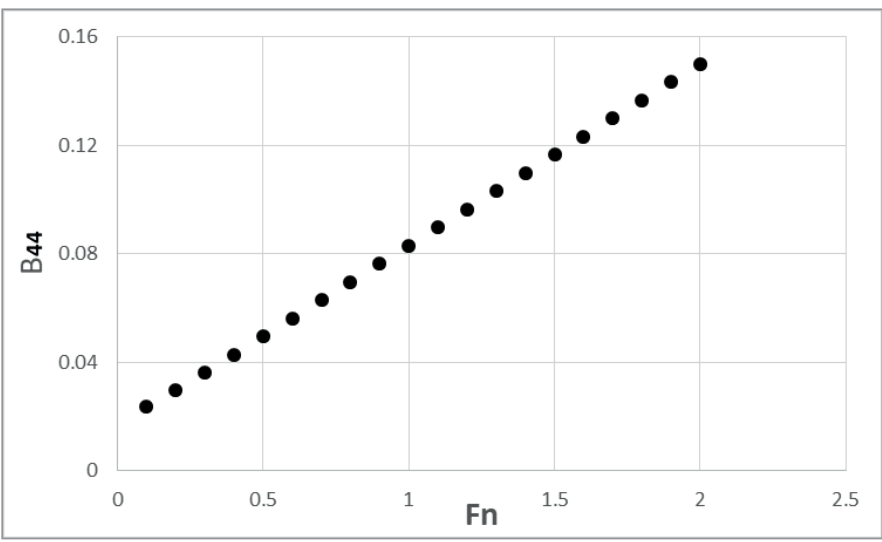

Figure 1. Roll damping values 
As shown in Fig.1, the roll damping coefficient increases with the forward speed. The regime of the curve is linear due to the biggest amount of contribution is provided by the lift and wave component. These roll damping coefficient values were used to determine the roll motion of the vessel.

$m_{1}=\frac{\Delta G M}{I+I_{x x}}$

$m_{3}=\frac{4 \omega \varphi^{2}}{\varphi_{v}^{2}}\left(\frac{3 A_{\varphi_{v}}}{G M \varphi_{v}^{2}}-1\right)$

$m 5=-\frac{3 \omega_{\varphi}^{2}}{\varphi_{v} 4}\left(\frac{4 A_{\varphi_{v}}}{G M \varphi_{v}^{2}}-1\right)$

The above mentioned restoring coefficients are determined via the GZ- $\Phi_{\mathrm{V}}$ curve. The right arm curve of the planning hull is represented in Fig.2. This figure indicates the correlation between GZ and $\Phi \mathrm{V}$. The area under the curve expresses that the planning hull is stable against external disturbances.

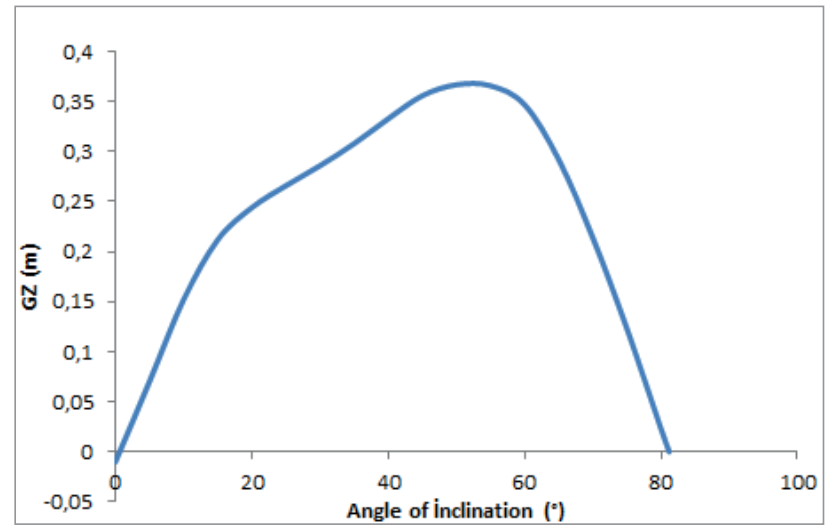

Figure 2. GZ- $\Phi_{\mathrm{V}}$ curve

After these significant calculations, the nonlinear roll motion equation can be expressed in state-space form as below,

$\dot{x}(t)=(A+\Delta A) x(t)+B_{1} w(t)+B_{2} u(t)$

where $\mathrm{x}(t) \in \mathfrak{R}^{n}$ is the state vector, $\mathrm{u}(t) \in \mathfrak{R}^{m}$ is the control input, $\mathrm{w}(t) \in \mathfrak{R}^{m}$ is the disturbance input. Then $\mathrm{A}, \mathrm{B}_{1}$ and $\mathrm{B}_{2}$, are known real constant state-space matrices with suitable dimensions.

$\Delta \mathrm{A}$ is a matrix valued function indicating time-varying parameter uncertainties. The parameter uncertainties are accepted to be norm bounded and of the following form,

$\Delta \mathrm{A}=\mathrm{GF}(t) \mathrm{E}_{\mathrm{A}}$

where $\mathrm{G}$ and $\mathrm{E}_{\mathrm{A}}$ are known, constant, real matrices in suitable dimensions which define the structure of uncertainties, and $\mathrm{F}(t)$ is an unknown matrix function with Lebesgue mensurable elements and satisfies $\mathrm{F}^{\mathrm{T}}(t) \mathrm{F}(t) \leq \mathrm{I}$ for all $t \geq 0$. State-space matrices are expressed as below associated with equation 11 and 12 . 
$A=\left[\begin{array}{ccc}0 & 1 & 0 \\ -m 1-\left(\left(m 3_{\text {max }}+m 5_{\text {max }}\right) / 2\right) & -\delta l-\left(\left(\delta 2_{\text {max }}+\delta 2_{\text {min }}\right)-\left(\left(\delta n_{\max }\right) / 2\right)\right. & -\left(\left(\delta 1_{\max }+\delta 1_{\text {min }}\right) / 2\right) \\ 0 & 0 & -t 1\end{array}\right]$

$B_{1}=\left[\begin{array}{lll}0 & \lambda_{e}\left(\omega_{e}^{\wedge} 2\right) \alpha_{m} & 0\end{array}\right]^{T}$

$B_{2}=\left[\begin{array}{lll}0 & 0 & t\end{array}\right]^{T}$

$G=\left[\begin{array}{ccc}0 & 0 & 0 \\ -\left(\left(m 3_{\max }+m 5_{\max }\right) / 2\right) & -\left(\left(\delta 2_{\max }-\delta 2_{\min }\right) / 2\right) & -\left(\left(\delta 1_{\max }-\delta 1_{\min }\right) / 2\right) \\ 0 & 0 & 0\end{array}\right]$

$E_{A}=I_{3 \times 3}$

As a result of these calculations, the necessary values are obtained for controller design and design procedure is explained detail in the following part.

\section{LMI Based Robust and Saturated $\mathrm{H}_{2}$ State Feedback Controller Design}

In this section, the LMI based robust and saturated $\mathrm{H}_{2}$ state feedback controller are designed for roll motion stabilization of a planning hull, using the theorem given below,

$\dot{x}(t)=\left(A+G F(t) E_{A}+B_{2} K\right) x(t)+B_{1} w(t)$

$z(t)=(C+D K) x(t)$

where $\mathrm{x}(t) \in \mathfrak{R}^{n}$ is the state vector, $\mathrm{z}(t) \in \mathfrak{R}^{p}$ is the controlled output vector. Then $\mathrm{A}, \mathrm{B}_{2}$, $\mathrm{B}_{1}, \mathrm{C}$ and $\mathrm{D}$ are known real constant state-space matrices with suitable dimensions.

For closed loop system, $\mathrm{H}_{2}$ norm is expressed in following form:

$\left\|T_{z w}\right\|_{2}=\sqrt{i z\left((C+D K) X_{c}(C+D K)^{T}\right)}$

$X_{c}$ as follows,

$\underbrace{\left(A+G F(t) E_{A}+B_{2} K\right)}_{\Psi} X_{c}+X_{c} \Psi^{T}+B_{1} B_{1}^{T}=0$

The above-mentioned expression is the solution of the Lyapunov equation.

If $\Psi$ is Hurwitz, by accepting $X \succ X_{c}$, the following inequalities are obtained (Dullerud \& Paganini, 2013).

$\Psi X+X \Psi^{T}+B_{1} B_{1}^{T} \prec 0$

$i z(\underbrace{(C+D K)}_{\Phi} X_{c} \Phi^{T})<i z(\underbrace{(C+D K)}_{\Phi} X \Phi^{T})$ 
By defining $L \in \mathfrak{R}^{\operatorname{mxn}}, L:=K X$

$\underbrace{A X+G F(t) E_{A} X+B_{2} L}_{\Omega}+\Omega^{T}+B_{1} B_{1}^{T} \prec 0$

$i z(\underbrace{(C X+D L)}_{\Lambda} X^{-1} \Lambda^{T})<i z(Q)$

inequalities are obtained.

Inequality (18) is defined as LMI using the following Lemma (Petersen \& Hollot, 1985).

Lemma [18]: $\bar{\Gamma}=\bar{\Gamma}^{T}$, J and H matrixes have suitable dimensions, the following expression is applied at this point

$\bar{\Gamma}+J F(t) H+H^{T} F^{T}(t) J^{T} \prec 0$

In addition, for $t \geq 0, \varepsilon>0$ and $F^{T}(t) F(t) \leq I$ can be used following LMI,

$\bar{\Gamma}+\frac{1}{\varepsilon} J J^{T}+\varepsilon H^{T} H \prec 0$

$J:=G$ and $H=E_{A} X$ are accepted for Lemma (Petersen \& Hollot, 1985). Applying the Schur complement (Boyd, Ghaoui, Feron \& Balakrishan, 1994), (17) and (18) matrix inequalities are expressed as described in (22) and (23)

$\left[\begin{array}{cc}\underbrace{A X+B_{2} L}_{\Pi}+\Pi^{T}+B_{1} B_{1}^{T}+\mu G G^{T} & X E_{A}^{T} \\ E_{A} X & -\mu I\end{array}\right] \prec 0$

$\left[\begin{array}{cc}Q & \Lambda \\ \Lambda^{T} & X\end{array}\right] \succ 0$

In addition, actuator saturation constraints are given as below,

$\left[\begin{array}{cc}X & L^{T} \\ L & u_{\max }^{2} I\end{array}\right] \succ 0$

$\left[\begin{array}{ll}Y & I \\ I & X\end{array}\right] \succ 0$

For $i z(Y)<\alpha$ and $i z(Q)<\eta$

The minimum $\alpha+\eta$ optimization problem can be solved using the constraints of $X=X^{T} \succ 0, L=L^{T} \succ 0, Y=Y^{T} \succ 0, Q=Q^{T} \succ 0, \mu>0$ and as a result $u(t)=L X^{-1} x(t)=K x(t)$ is determined 


\section{Simulation Results}

In this paper, a roll stabilization controller is designed by using fins as the control actuators for the planning hull. The fin stabilizer geometry chosen is the NACA 0015 foil section which is widely used in the literature. The flow analyses are performed using commercial computational fluid dynamics (CFD) software based on the finite volume method. The flow problem is modelled in a 3-dimensional manner while the flow is considered as steady, incompressible and fully turbulent. The maximum lift coefficient value is used for controller design. The Computational Fluid Dynamics (CFD) calculations for the lift are illustrated in Figure 3.

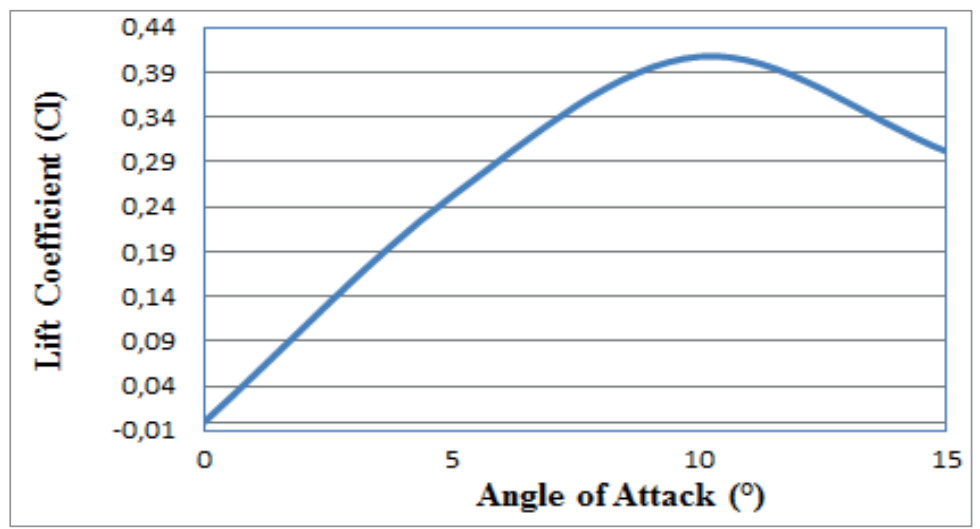

Figure 3. Lift coefficients versus angle of attack graph

The dynamic characteristics of the planning hull and the fin stabilizer particulars (NACA 0015) are given in Table 1.

Table 1. Principal particulars of the planing hull and fin roll stabilizer

\begin{tabular}{|l|c|c|}
\hline Principal Particulars & Symbol & Parameter \\
\hline Length between perpendiculars & $L_{\mathrm{bp}}$ & $16.95 \mathrm{~m}$ \\
\hline Breadth & $B$ & $4.94 \mathrm{~m}$ \\
\hline Depth & $D$ & $2.78 \mathrm{~m}$ \\
\hline Draught & $T$ & $1.229 \mathrm{~m}$ \\
\hline Displacement & $\Delta$ & $54.788 \mathrm{~m}^{3}$ \\
\hline Metacentric height & $G M$ & $0.921 \mathrm{~m}$ \\
\hline Vertical center of gravity & $K G$ & $2.196 \mathrm{~m}$ \\
\hline Block coefficient & $C_{\mathrm{B}}$ & 0.36 \\
\hline Max speed & $V_{\max }$ & $15 \mathrm{kn}$ \\
\hline Min speed & $V_{\min }$ & $6 \mathrm{kn}$ \\
\hline Fins area & $A_{\mathrm{F}}$ & $2.08 \mathrm{~m}^{2}$ \\
\hline Fins lift coefficient & $C_{\mathrm{L}}$ & 0.4 \\
\hline Vanishing angle of stability & $\varphi_{v}$ & $81.2^{0}$ \\
\hline
\end{tabular}

Robust and saturated control via LMIs was applied to the dynamics of the roll motions of the planning hull. Application of the proposed control system is illustrated in the following figures for different speeds. 


\section{For 6 kn;}

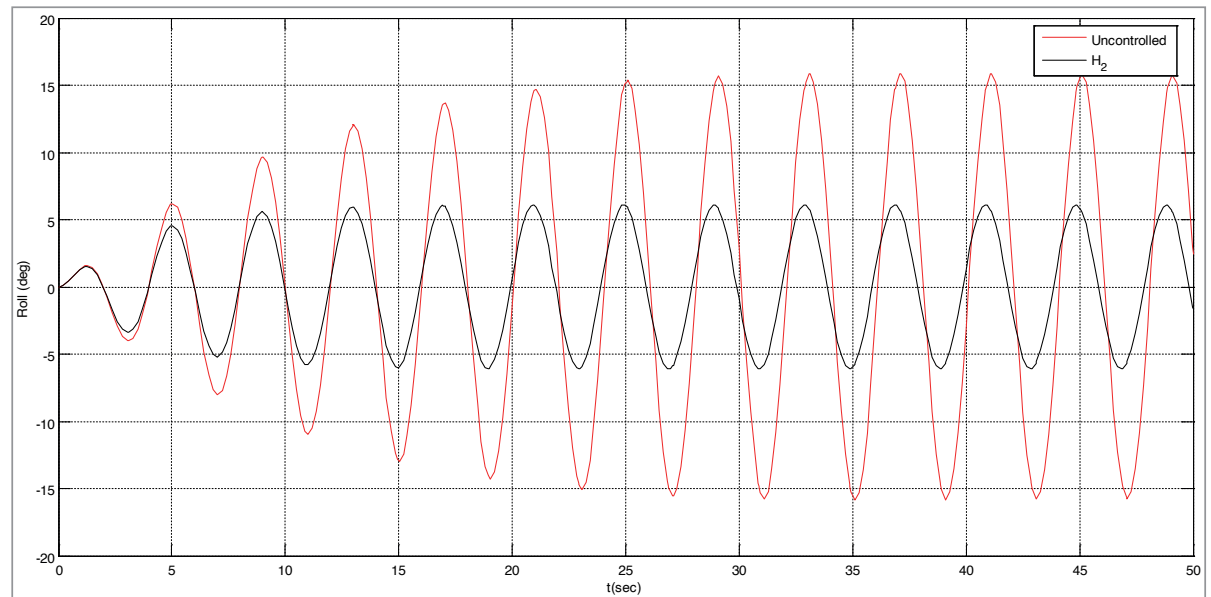

Figure 4. Roll angle response for uncontrolled and controlled condition

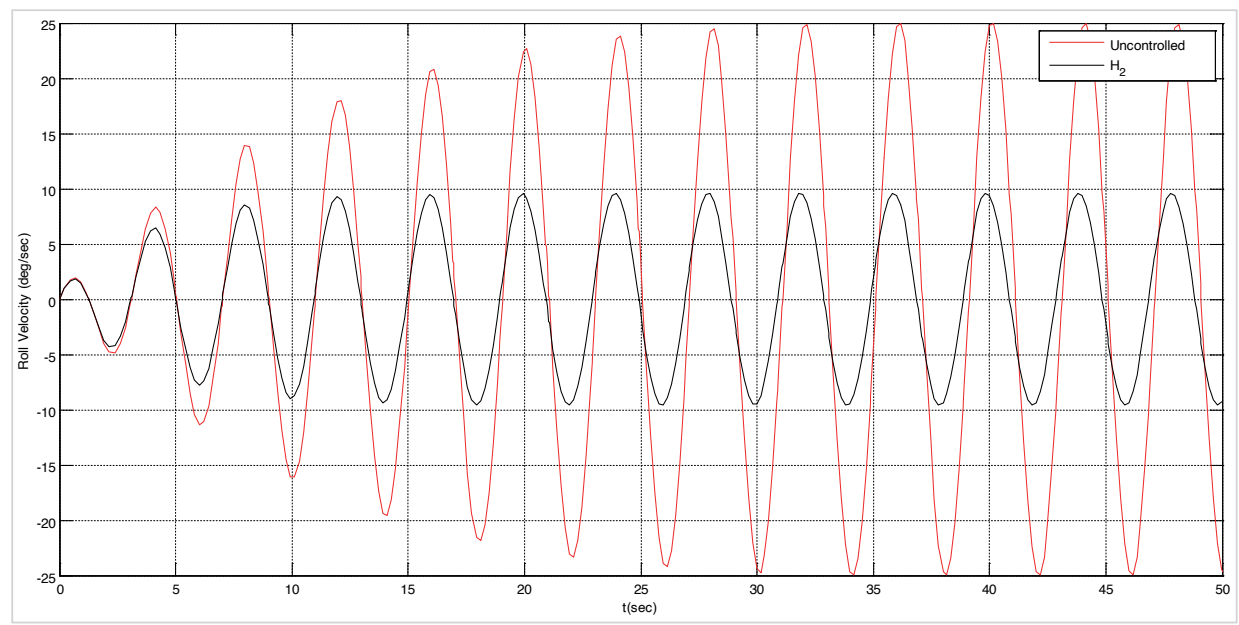

Figure 5. Roll velocity response for uncontrolled and controlled condition

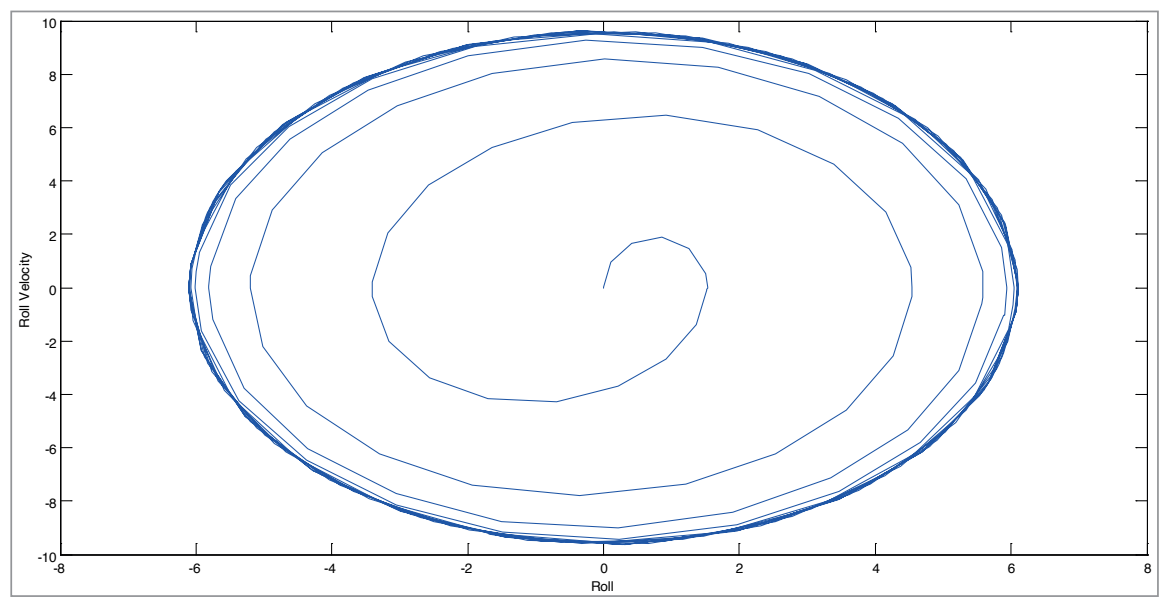

Figure 6. Phase diagram for controlled condition 


\section{For 15 kn;}

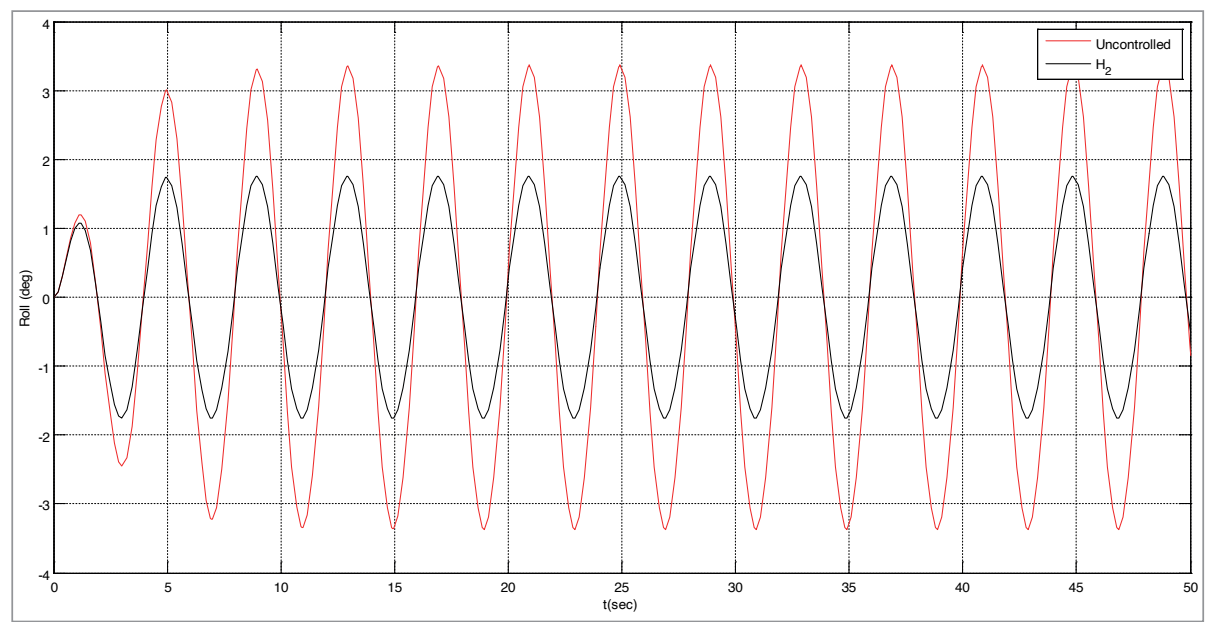

Figure 7. Roll angle response for uncontrolled and controlled condition

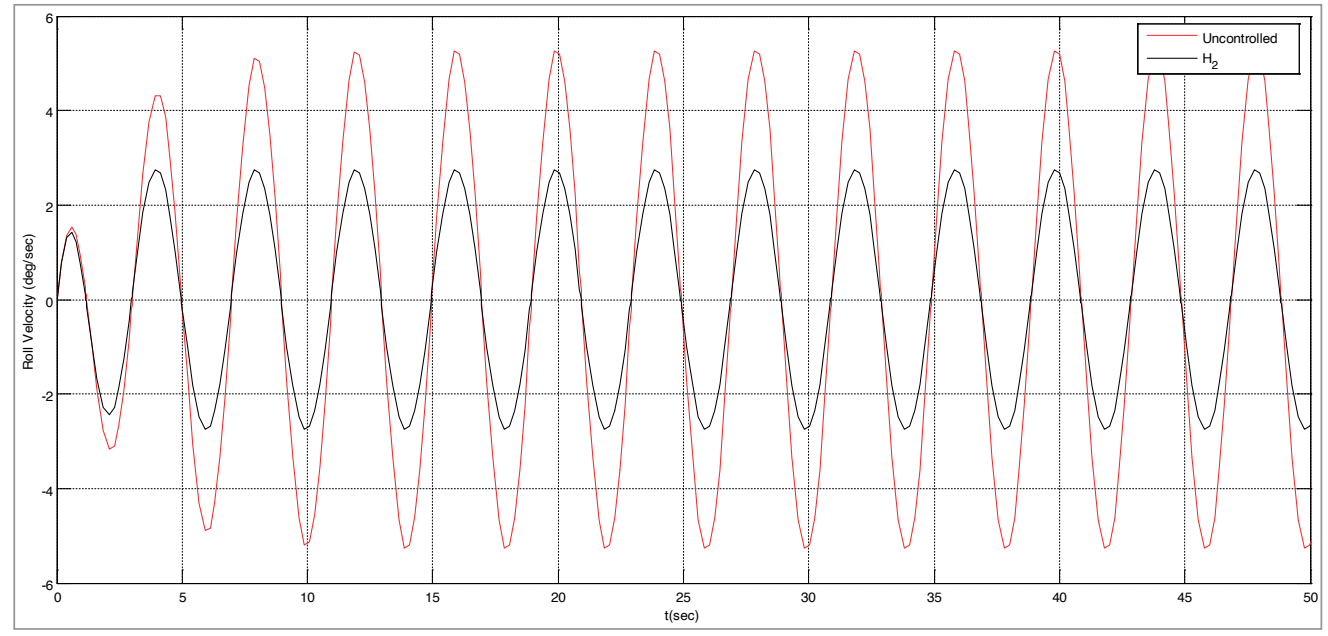

Figure 8. Roll velocity response for uncontrolled and controlled condition

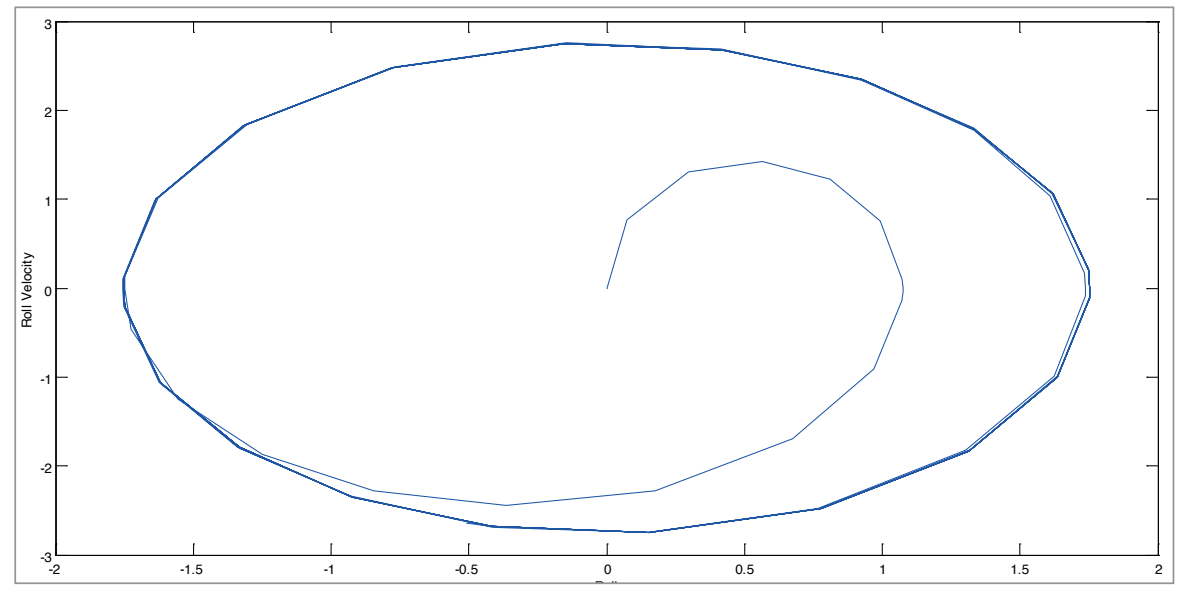

Figure 9. Phase diagram for controlled condition 
The simulations show that the obtained results are applicable and effective for controlling roll motion of the planning hull. Robust and saturated $\mathrm{H}_{2}$ state feedback controller achieved considerable roll reduction against external disturbances.

\section{Conclusion}

This paper deals with the LMI based robust and saturated $\mathrm{H}_{2}$ state feedback control problem for the roll motion of planning hull with the fin stabilizer system. The Computational Fluid Dynamics (CFD) calculations for the lift coefficients are determined using Star CCM + software. The maximum lift coefficient is used for controller design. The robust and saturated $\mathrm{H}_{2}$ state feedback controller algorithm for the planning hull has been designed and simulation results have been presented. According to the simulation results, it can be observed that LMI based robust and saturated $\mathrm{H}_{2}$ state feedback controller shows significant improvement in roll reduction for safety transportation.

Peer-review: Externally peer-reviewed.

Conflict of Interest: The authors has no conflict of interest to declare.

Grant Support: The authors declared that this study has received no financial support.

Hakem Değerlendirmesi: Dış bağımsız.

Çıkar Çatışması: Yazarlar çıkar çatışması bildirmemiştir.

Finansal Destek: Yazarlar bu çalışma için finansal destek almadığını beyan etmiştir.

\section{References}

Alarcin, F., \& Gulez, K. (2007). Rudder roll stabilization for fishing vessel using neural network approach. Ocean engineering, 34(13), 1811-1817.

Bai, R. (2014). Adaptive fuzzy output-feedback method applied to fin control for time-delay ship roll stabilization. Mathematical Problems in Engineering, 2014.

Boyd, S., El Ghaoui, L., Feron, E., \& Balakrishnan, V. (1994). Linear matrix inequalities in system and control theory (Vol. 15). Siam.

Chadwick, J. H. (1955). On the stabilization of roll. Transactions of the Society of Naval Architects and Marine Engineers, 63, 237-280.

Dullerud, G. E., \& Paganini, F. (2013). A course in robust control theory: a convex approach (Vol. 36). Springer Science \& Business Media.

Ghassemi, H., Dadmarzi, F., Ghadimi, P., \& Ommani, B. (2010). Neural network-PID controller for roll fin stabilizer. Polish Maritime Research, 17(2), 23-28.

Guo, Z., Lin, Z., Yang, Q., \& Li, X. (2012). Research of combined control scheme for fast catamaran motion control using T-foils and interceptors. International Journal of Intelligent Engineering \& Systems, 5(2), 1-8.

Hickey, N. A., Johnson, M. A., Katebi, M. R., \& Grimble, M. J. (1999, August). PID controller optimisation for fin roll stabilisation. In Proceedings of the 1999 IEEE International Conference on Control Applications (Cat. No. 99CH36328) (Vol. 2, pp. 1785-1790). IEEE.

Himeno, Y. (1981). Prediction of ship roll damping-a state of the art. University of Michigan.

Holden, C., Galeazzi, R., Fossen, T. I., \& Perez, T. (2009, August). Stabilization of parametric roll resonance with active u-tanks via lyapunov control design. In 2009 European Control Conference (ECC) (pp. 4889-4894). IEEE.

Ikeda, Y. (1978). A prediction method for ship roll damping. Report No. 00405 of the Department of Naval Architecture. 
Ikeda, Y., \& Katayama, T. (2000, February). Roll damping prediction method for a high-speed planing craft. In Proc. 7th Intl. Conf. Stability of Ships and Ocean Vehicles.

Katayama, T., \& Ikeda, Y. (1995). An experimental study on transverse stability loss of planing craft at high speed in calm water.

Ku, C. C., \& Li, M. D. (2015). A mixed H 2/passivity performance controller design for a drum-boiler system. Journal of Marine Engineering \& Technology, 14(3), 137-145.

Marzouk, O. A., \& Nayfeh, A. H. (2009). Control of ship roll using passive and active anti-roll tanks. Ocean engineering, 36(9-10), 661-671.

Peng, X., Jia, S., \& Yu, Y. (2014, July). A nonlinear control method based on fuzzy optimization algorithm for rudder roll stabilization. In Proceedings of the 33rd Chinese Control Conference (pp. 7888-7891). IEEE.

Perez, T. (2006). Ship motion control: course keeping and roll stabilisation using rudder and fins. Springer Science \& Business Media.

Petersen, I. R., \& Hollot, C. V. (1986). A Riccati equation approach to the stabilization of uncertain linear systems. Automatica, 22(4), 397-411.

Qi, Z. G., Jin, H. Z., Liu, W. Y., \& Xu, Y. (2014, April). Research on active fin stabilizer at low speed and its application to ship roll stabilization. In OCEANS 2014-TAIPEI (pp. 1-6). IEEE.

Saari, H., \& Khichane, E. (2013). Robust rudder roll reduction of container ship. Journal of Automation and Systems Engineering, 7(3), 94-104.

Taylan, M. (1990). Application of nonlinear roll motion model for assessment of ship stability in waves. Florida Institute of Technology.

Townsend, N. C., \& Shenoi, R. A. (2013). Control strategies for marine gyrostabilizers. IEEE Journal of Oceanic Engineering, 39(2), 243-255. 
